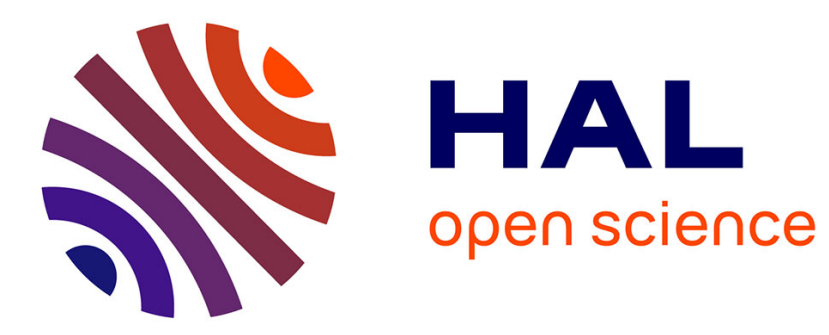

\title{
Female imperialism and national identity. Imperial Order Daughters of the Empire
}

\author{
Andrea Petö
}

\section{To cite this version:}

Andrea Petö. Female imperialism and national identity. Imperial Order Daughters of the Empire. National Identities, 2014, 16, pp.184 - 185. 10.1080/14608944.2014.883567 . hal-03232946

\section{HAL Id: hal-03232946 \\ https://hal.science/hal-03232946}

Submitted on 22 May 2021

HAL is a multi-disciplinary open access archive for the deposit and dissemination of scientific research documents, whether they are published or not. The documents may come from teaching and research institutions in France or abroad, or from public or private research centers.
L'archive ouverte pluridisciplinaire HAL, est destinée au dépôt et à la diffusion de documents scientifiques de niveau recherche, publiés ou non, émanant des établissements d'enseignement et de recherche français ou étrangers, des laboratoires publics ou privés. 
This article was downloaded by: [Central University]

On: 19 February 2014, At: 08:40

Publisher: Routledge

Informa Ltd Registered in England and Wales Registered Number: 1072954 Registered

office: Mortimer House, 37-41 Mortimer Street, London W1T 3J H, UK

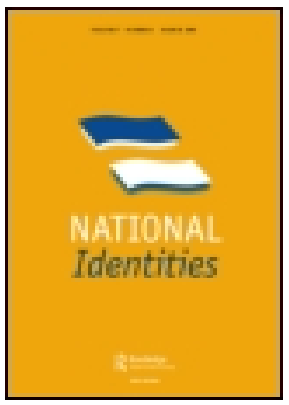

\title{
National Identities
}

Publication details, including instructions for authors and

subscription information:

http:// www.tandfonline.com/loi/ cnid20

\section{Female imperialism and national identity. Imperial Order Daughters of the Empire}

\author{
Andrea Petö ${ }^{\mathrm{a}}$ \\ a Department of Gender Studies, Central European University, \\ Budapest, Hungary \\ Published online: 14 Feb 2014.
}

To cite this article: Andrea Pető , National Identities (2014): Female imperialism and national identity. Imperial Order Daughters of the Empire, National Identities, DOI:

10.1080/14608944.2014.883567

To link to this article: http:// dx.doi.org/ 10.1080/ 14608944.2014.883567

\section{PLEASE SCROLL DOWN FOR ARTICLE}

Taylor \& Francis makes every effort to ensure the accuracy of all the information (the "Content") contained in the publications on our platform. However, Taylor \& Francis, our agents, and our licensors make no representations or warranties whatsoever as to the accuracy, completeness, or suitability for any purpose of the Content. Any opinions and views expressed in this publication are the opinions and views of the authors, and are not the views of or endorsed by Taylor \& Francis. The accuracy of the Content should not be relied upon and should be independently verified with primary sources of information. Taylor and Francis shall not be liable for any losses, actions, claims, proceedings, demands, costs, expenses, damages, and other liabilities whatsoever or howsoever caused arising directly or indirectly in connection with, in relation to or arising out of the use of the Content.

This article may be used for research, teaching, and private study purposes. Any substantial or systematic reproduction, redistribution, reselling, loan, sub-licensing, systematic supply, or distribution in any form to anyone is expressly forbidden. Terms \& Conditions of access and use can be found at http://www.tandfonline.com/page/termsand-conditions 


\section{BOOK REVIEW}

Female imperialism and national identity. Imperial Order Daughters of the Empire, by Katie Pickles, Manchester and New York, Manchester University Press, 2009 (first hardback edition in 2002), v-xi + 209 pp., £15.99 (paperback), ISBN 978-0-7190-6391-6

It is not unproblematic for gender historians (and therefore it appeals to few of them) to write about the history of non-progressive women activists. Katie Pickles selected as the subject of her well-researched book a group of women who are difficult to like or to sympathise with. The members of the Imperial Order of the Daughters of the Empire, a women's organisation founded in 1900, are a snobbish, white Anglo-Saxon Protestant local elite from Canadian cities who cultivated the British Imperial connection even after the Empire was long gone. For the membership of the Order, the existence of French Canada is an ignorable unfortunate fact. But this organisation is not just another philanthropic organisation which emerged at the turn of the nineteenth century, for its century-long history, masterfully narrated by Pickles, can enrich our knowledge about imperialism, gender and more specifically about women's activism on the right. At the peak of its popularity (before the First World War), this organisation of 'feminists of the right' attracted 50,000 members in central Canada alone. In her book, Katie Pickles has not only managed to make the motivations of these women understandable for, by the end of the book, the reader feels sympathy with their heroic efforts to ignore passing times. How does the author achieve this?

First, the book is based on finding all possible pieces of archival information about the Order. The fact that self-documenting zeal was high among its members of course helps the present-day historian with her work. But she also travelled within and outside of Canada, investigating all possible private and public collections. The book consists not only of detailed membership lists for the whole of Canada, but also of maps showing where the Order was active.

Second, the author 'allows the material to speak' in the sense that the activity of the Order cuts across all possible traditional periodisations and chronology. Pickles follows a chronological order when presenting her material, but acknowledges the fact that the lives and ideas of women whom she has been researching might not necessarily coincide with the categories of canonised history. This makes the book a very interesting read because it reveals how personal continuities often ignore ruptures and cleavages of the 'grand narratives'.

Third, the book is an atypical historical work because the author wisely recognised that the Order is thriving even today, and she had an opportunity to interview its members and activists about how they narrate their own activity. As a historian, Pickles presents the facts she found in the documents, press and in correspondence. The problem remains, however, that she analyses visual sources and oral sources in the same way as she analyses texts, and therefore disregards emerging methodological problems. The author 
ignores the fact that self-presentations of members of the Order in the interviews are constructions, not the 'truth'.

The structure of the book is clear. After a brief overview of the genealogy of gender and empire, the author presents the history of the Order from its foundation in 1900 until 1919, introducing 'female imperialism at the periphery'. This is followed by chapters telling the story of how the 'female imperialist' could accommodate her identity with and within independent Canada. The most remarkable part of the book is the chapter which introduces the invented tradition of imperial tradition and knowledge, and illustrates how stereotypical female characteristics created a space for these women for public action. The book closes with a chapter describing the activism of the order in Canada during the cold war, and concludes by analysing the contribution made by the Order to the modernisation of the north, and the internal colonisation of indigenous people.

Pickles successfully uncovers the secret of the enduring popularity of the Order, which still had 10,000 active members even in 1993. Its organisational structure, stable hierarchy and ability to act immediately helped the organisation to outlive the empire it was meant to serve. What remained of this legacy is the tight network of elite women who recruited their daughters and daughters-in-law as 'daughters' for their beloved organisation and its remarkable and enviable historical past. These women of the Order had access to public space (more precisely local space, rarely to that of national politics) by means of their acceptance of the patriarchal division of public and private realms. But using the privilege born from the intersection of class and gender position, the dedicated fighters of British imperialism, anticommunism and national fitness were able to invade 'masculine' spaces. This also proves that egalitarianism, which is a foundational myth of the white settler society, does not apply to femininity or to colonial elites in general. The very important 'firsts' in Canadian women's history, which include the first woman mayor, federal minister or chancellor of a Canadian university, all came from this intellectual, emotional and psychological cradle, a fact which proves that 'feminist outcomes can come from a variety of motives' (p. 177). There is a lot which today's women's activists can learn from the persistence, efficiency and idealism of members of the Order in their commitment to causes that had been long declared outdated.

Andrea Pető

Department of Gender Studies, Central European University, Budapest, Hungary petoand@t-online.hu (C) 2014, Andrea Pető http://dx.doi.org/10.1080/14608944.2014.883567 